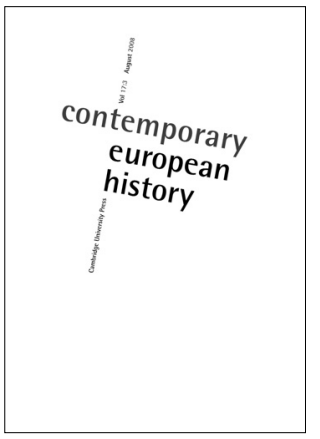

Contemporary European History is available online at:

http://journals.cambridge.org/ceh

To subscribe contact

Customer Services

in Cambridge:

Phone +44 (0) 1223326070

Fax +44 (0)1223 325150

Emailjournals@cambridge.org

\section{in New York:}

Phone (845) 3537500

Fax (845) 3534141

Email

subscriptions_newyork@cambridge.org

\section{Contemporary European History}

\section{Editors}

Mary Vincent, University of Sheffield, UK

Neville Wylie, University of Nottingham, UK

\section{Corresponding Editor for North America}

John Connelly, University of California, Berkeley, USA

\section{Associate Editor}

Holger Nehring, University of Sheffield, UK

Contemporary European History focuses on twentiethcentury European history in its broadest sense. It encompasses Eastern and Western Europe and covers the period from 1918 to the present. It is open to all forms of inquiry - including cultural, economic, international, political and social history - and welcomes comparative approaches.

\section{Price information is available at: http://journals.cambridge.org/ceh}

\section{Free email alerts}

Keep up-to-date with new material - sign up at http://journals.cambridge.org/alerts

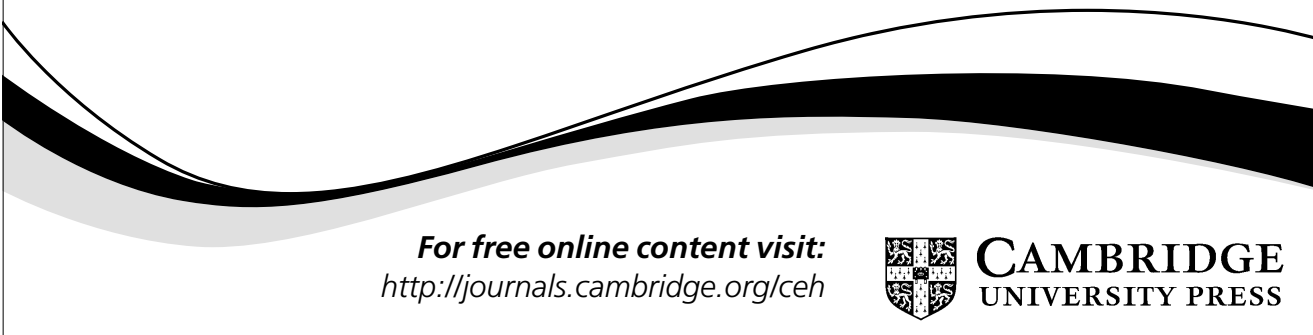




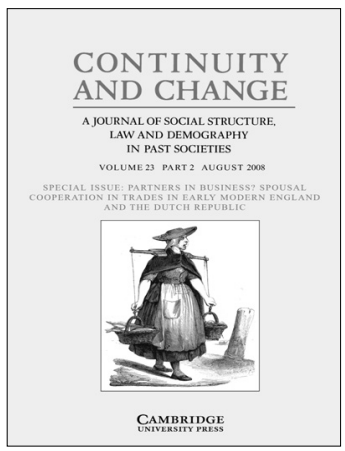

continuity and change

is available online at:

http://journals.cambridge.org/con

To subscribe contact

Customer Services

\section{in Cambridge:}

Phone +44 (0)1223 326070

Fax +44(0)1223 325150

Emailjournals@cambridge.org

\section{in New York:}

Phone (845) 3537500

Fax (845) 3534141

Email

subscriptions_newyork@cambridge.org

\section{CONTINUITY AND CHANGE}

A journal of social structure, law and demography

in past societies

\section{Editors}

Richard Wall, University of Essex, UK Lloyd Bonfield, Tulane Law School, USA

Phillipp Schofield, University of Wales, Aberystwyth, UK

Continuity and Change aims to define a field of historical sociology concerned with long-term continuities and discontinuities in the structures of past societies. Articles combine elements from areas such as history, law, economics or anthropology. Comparative studies over a broad range of cultures and time spans are encouraged.

\section{Price information is available at: http://journals.cambridge.org/con}

\section{Free email alerts}

Keep up-to-date with new material - sign up at http://journals.cambridge.org/alerts

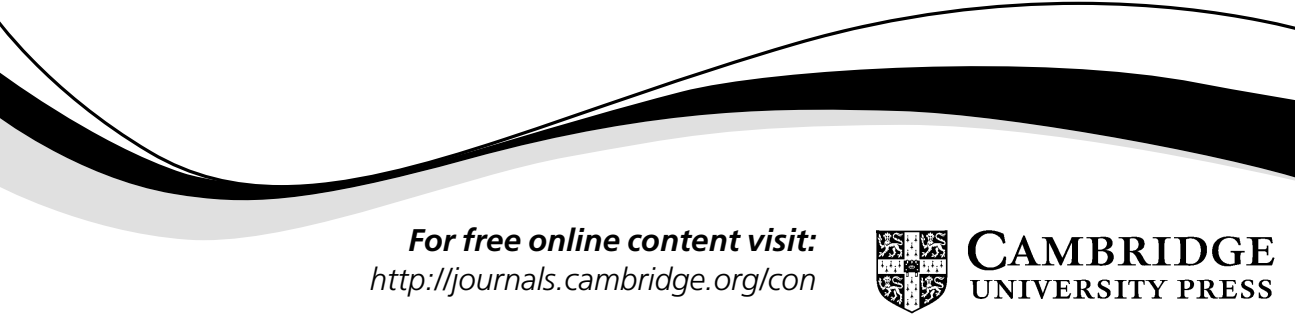




\section{CAMBRIDGE}

Our most celebrated reference series is now a click away...

\section{CAMBRIDGE HISTORIES ONLINE}

A unique historical reference compendium

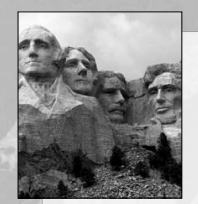

Political Thought • Ancient History

$$
\text { Japan • Iran }
$$

Medieval History • Science Russia

Native Peoples of the Americas

Irish Literature • Latin America

Literary Criticism - The English Language

British Theatre • Music

African and Caribbean Literature

China $\bullet$ Judaism

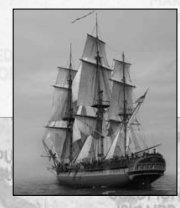

And much more!

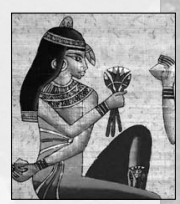

Get a free trial today.

Contact: online@cambridge.org

www.cambridge.org/online/histories 


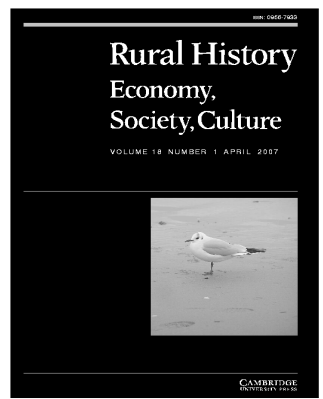

Rural History

is available online at:

journals.cambridge.org/ruh

To subscribe contact

Customer Services

\section{in Cambridge:}

Phone +44 (0)1223 326070

Fax +44 (0)1223 325150

Emailjournals@cambridge.org

\section{in New York:}

Phone (845) 3537500

Fax (845) 3534141

Email

subscriptions_newyork@cambridge.org

\section{Rural \\ History}

\section{Editors}

Liz Bellamy, University of East Anglia, UK

Keith D. M. Snell, University of Leicester, UK

Tom Williamson, University of East Anglia, UK

Rural History is a stimulating forum for interdisciplinary exchange. Subject areas include: agricultural history; historical ecology; folklore; popular culture and religion; literature; landscape history, archaeology and material culture; ethnography, anthropology and sociology; women in rural societies; relationships between the urban and the rural; and the politics of rural societies.

Price information is available at: journals.cambridge.org/ruh

\section{Free email alerts} Keep up-to-date with new material sign up at journals.cambridge.org/register

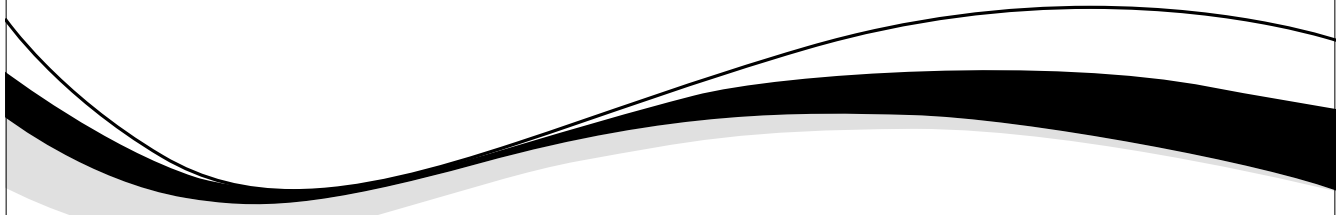

For a free online sample visit: journals.cambridge.org/ruh 
SUBSCRIPTIONS Urban History (ISSN 0963-9268) is published three times a year in May, August and December. Three parts form a volume. The subscription price of volume 36 (2009) (which includes print and electronic access) is $£ 146$ (US\$227 in the USA, Canada and Mexico) for institutions. The electronic only price available to institutional subscribers is $£ 128.00$ (US\$214 in the USA, Canada and Mexico). $£ 40$ (US\$70 in the USA, Canada and Mexico) for individuals $£ 20$ (US\$35 in the USA, Canada and Mexico) for students ordering direct from the publisher and certifying that the journal is for their personal use. Single parts are $£ 48$ (US\$80 in the USA, Canada and Mexico) plus postage.

Orders, which must be accompanied by payment, may be sent to a bookseller, subscription agent or direct to the publisher: Cambridge University Press, The Edinburgh Building, Shaftesbury Road, Cambridge CB2 8RU; or in the USA, Canada and Mexico: Cambridge University Press, Journals Fulfillment Department, 100 Brook Hill Drive, West Nyack, New York 10994-2133. Copies of the journal for subscribers in the USA, Canada and Mexico are sent by air to New York to arrive with minimum delay. Japanese prices for institutions are available from Kinokuniya Company Ltd, P.O. Box 55, Chitose, Tokyo 156, Japan. Prices include delivery by air.

COPYING This journal is registered with the Copyright Clearance Center, 222 Rosewood Drive, Danvers, MA 01923, USA. Organizations in the USA who are also registered with C.C.C. may therefore copy material (beyond the limits permitted by sections 107 and 108 of U.S. Copyright law) subject to payment to C.C.C. of the per-copy fee of $\$ 12.00$. This consent does not extend to multiple copying for promotional or commercial purposes. Code 0963-9268/2008/\$12.00.

ISI Tear Sheet Service, 3501 Market Street, Philadelphia, PA 19104, USA, is authorized to supply single copies of separate articles for private use only.

Organizations authorized by the Copyright Licensing Agency may also copy material subject to the usual conditions. For all other use, permission should be sought from Cambridge or from the American Branch of Cambridge University Press.

This journal is included on the Cambridge Journals Online Service, which can be found at http://www.journals. cambridge.org. For further information on other press titles access http:/ / www.cambridge.org

\section{Instructions for contributors}

\section{Editorial policy}

Urban History occupies a central place in historical scholarship. Contents include research-based articles, historiographical and methodological surveys, and surveys of urban development in individual countries. As part of a major contribution to research, Urban History provides detailed bibliographical references for an average of 1,000 classified and indexed items, culled from monographs and edited collections, and from approximately 560 periodicals.

\section{Submissions}

Submissions from authors on all aspects of urban history are invited. Articles of a comparative or thematic nature are encouraged, as are articles which raise methodological issues, and those which seek to place the development of individual towns or cities in a wider framework. No historical period is excluded.

Articles submitted for publication should be sent to The Editors, Urban History, Centre for Urban History, University of Leicester, Leicester LE1 7RH, UK, or by email at sg201@le.ac.uk or rhs4@le.ac.uk Authors wishing to submit articles on North American topics should contact Philip Ethington on philipje@usc.edu

Submission of a paper will be taken to imply that it is unpublished and is not being considered for publication elsewhere. Upon acceptance of a paper, the author will be asked to assign copyright (on certain conditions) to Cambridge University Press.

Contributors are responsible for obtaining permission to reproduce any material in which they do not hold copyright and for ensuring that the appropriate acknowledgements are included in their manuscript.

\section{Manuscript preparation}

Articles should be no longer than 8,000 words, inclusive of footnotes and tables, and should be double spaced throughout. A summary of 75 words should also be provided.

Further information and detailed 'Instructions for contributors' visit www.journals.cambridge.org/uhy.

This journal issue has been printed on FSC-certified paper and cover board. FSC is an independent, non-governmental, not-for-profit organization established to promote the responsible management of the world's forests. Please see www.fsc.org for information. 


\section{URBAN HISTORY}

Volume 36 Part 2 August 2009

Special Issue: Transnational Urbanism in the Americas

Edited by Philip J. Ethington, Janice L. Reiff and David P. Levitus, Associate Editor

\section{CONTENTS}

List of books reviewed

Introduction

JANICE L. REIFF and PHILIP J. ETHINGTON

Competing scales in transnational networks: the impossible travel of Patrick

Geddes' Cities Exhibition to America, 1911-1913

PIERRE CHABARD

From body and home to nation and world: the varying scales of transnational urbanism in Montreal and Brussels at the turn of the twentieth century

NICOLAS KENNY

Timely innovations: planes, trains and the 'whites only' economy of a

Pan-American city

N. D. B. CONNOLLY

Jaqueline Tyrwhitt and transnational discourse on modern urban planning and design, 1941-1951

ELLEN SHOSHKES

Tracing urban design's 'Townscape' origins: some relationships between

a British editorial policy and an American academic field in the 1950s

CLÉMENT ORILLARD

The Alliance for Progress and housing policy in Rio de Janeiro

and Buenos Aires in the 1960s

LEANDRO BENMERGUI

Review essay

Beyond nationalism: modernity, governance and a new urban history for India

JANAKI NAIR

Reviews of books

VANESSA HARDING, KATY LAYTON-JONES and AMANDA SELIGMAN

Cover illustration: Vila Kennedy, Rio de Janeiro, c. 1965. COHAB-GB, A COHAB através de números e imagens (Rio de Janeiro, 1965).

See Multimedia Companion to this Issue:

www.journals.cambridge.org/ urbanhistoryextra

Cambridge Journals Online

For further information about this journal please go to the journal website at: journals.cambridge.org/uhy 